\title{
FACTORS AFFECTING EMPLOYEE PERFORMANCE AND ORGANIZATIONAL PERFORMANCE AT PT. BANK ACEH SYARIAH
}

\author{
*Hasanuddin, Nasir and Ridwan \\ Department of Managent, Universities Syiah, Kuala, Indonesia \\ http://doi.org/10.35409/IJBMER.2019.2429
}

\begin{abstract}
The purpose of this study was to determine (1) the influence of motivation, organizational climate and work discipline on employee performance, (2) the influence of motivation, organizational climate and work discipline on the performance of PT. Bank Aceh Syariah, (3) the effect of employee performance on the performance of PT. Bank Aceh Syariah and indirect influence of motivation, organizational climate and work discipline on performance through employee performance variables of PT. Bank Aceh Syariah. The size of the population is employees of PT. Bank Aceh Syariah totaling 1,899 people. The sample used in this study is 137 employees of PT. Bank Aceh Syariah chosen by proportionate random sampling. The result describes that motivation effects employee performance significantly, organizational climate effects employee performance significantly, work discipline effects employee performance significantly, motivation effects organizational performance significantly, organizational climate effects organizational performance significantly, work discipline effects $n$ organizational performance significantly, and employee performance effects organizational performance significantly. These all findings strengthen the previous theories and being the new premises. Work discipline is the biggest factor affecting the performance of employees of PT. Bank Aceh Syariah. Motivation is also the most dominant factor affecting the organizational performance of PT. Bank Aceh Syariah. This model can be a basic for another research in further and this also can enrich the realm of knowledge especially in management. For practical managers, this is also as a reference for leaders to consider and pay more attention to the variables related. The limitation lies in the number of variables and object.
\end{abstract}

Keyword: Motivation, Organizational Climate, Work Discipline, Employee Performance and Organizational Performance

\section{INTRODUCTION}

Anindividual performance can increase due to several factors.(Halimah, Mukhlis and Amri, 2016) shows that work motivation, leadership, work discipline and work stress are related to the performance of the Aceh Social Service. Employee performance is related to the performance of the Aceh Social Service and there are direct and indirect relationships of work motivation, work discipline, leadership and work stress on the performance of the Aceh Social Service through the performance of Aceh Social Service staff. 


\section{International Journal of Business Management and Economic Review}

Vol. 2, No. 06; 2019

ISSN: 2581-4664

(Dodi, Mukhlis and Amri, 2013) shows that work ethic, organizational climate, and work discipline are related to the performance of employees of PT. Arun. Employee performance influences organizational performance. Work ethic, organizational climate, and work discipline affect organizational performance through employee performance. Work ethic, organizational climate, and work discipline affect the organizational performance of PT. Arun.

PT Bank Aceh Syariah is a business entity in the field of banking services. In carrying out its activities PT Bank Aceh Syariah has a mission so that all employees perform their duties properly.

As the number of branch offices increased, the performance of PT Bank Aceh Syariah in 20162017 also showed a significant increase, it was noted that assets, profits and lending PT Bank Aceh Syariah experienced an increase and managed to achieve performance through assets worth Rp. 23.567 trillion in the third quarter of 2017 or a significant increase of $17.10 \%$ compared to the third quarter of 2016 which was only Rp. 20.126 trillion. The same achievement was also achieved in the profit in the third quarter of 2017 amounting to Rp. 295 billion or an increase of 1,789.72\% from the third quarter of 2016 Rp. 15 billion. Increases also occur in terms of lending from Rp. 12,084 trillion in 2016 to Rp. 12,486 trillion in 2017, PT Bank Aceh also succeeded in reducing the number of non-performing loans (NPF) financing from $0.23 \%$ to $0.04 \%$. But behind the positive phenomenon shown by the performance of PT Bank Aceh Syariah as explained, there are still a number of negative phenomena that are shown by employee performance. A good organization is determined by the performance of its employees. Organizational performance is a success or failure of organizational goals (Sulityani, 2009).Factors related to organizational performance used by the author are motivation, work discipline and organizational climate. To assess organizational performance, a balance scorecard analysis is used. (Armstrong, 2006)in (Fahmi, 2011) say performance is the result of work related to the ultimate goal of an organization, customer satisfaction and contributing to the economy. Motivation comes from the word motif, meaning the driving force has an effect on the readiness to start activities on an individual behavior. Motivation can be seen from the pattern and behavior. Motivation in terms of changes in energy in a person's person in the form of feelings, preceded by responses to the existence of goals achieved (Mangkunegara, 2013). Organizational climate is inherent from the workplace environment or psychologically in the organization that is felt by its members and is considered influential on changes in workers' behavior in carrying out their work (Gibson and Callister, 2010).(Sinungan, 2011)stated that discipline is the condition of people who are members of organizations subject to rules with happy hearts. While work is human activity carried out in reaching the goal.

From the discussion above concludes that Factors that affect performance are the workforce or the individual human being that is related to motivation, organizational climate, and work discipline. Problems that are often faced by employees of PT. Bank Aceh, among others, relates to the achievement of targets imposed on employees, but in general the performance of employees of PT. Bank Aceh Syariah is good enough even though there is still a small percentage of employees who give negative responses.

From the disscussion above, the research model and the hypothesis that can be formulated is as follow, 


\section{International Journal of Business Management and Economic Review}

Vol. 2, No. 06; 2019

ISSN: 2581-4664

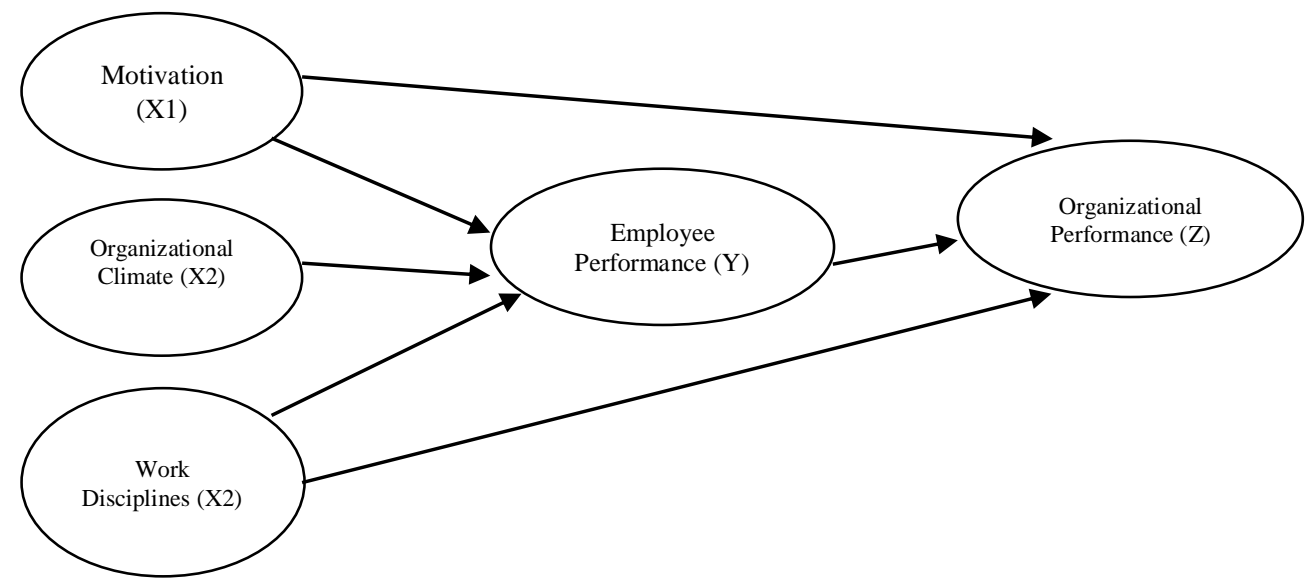

Figure 1. Research paradigm

H1 : motivation effects employee performance significantly

$\mathrm{H} 2$ :organizational climate effects employee performance significantly

$\mathrm{H} 3$ : work discipline effects employee performance significantly

$\mathrm{H} 4$ : motivation effects organizational performance significantly

H5 : organizational climate effects organizational performance significantly

$\mathrm{H} 6$ : work discipline effects $\mathrm{n}$ organizational performance significantly

$\mathrm{H} 7$ : employee performance effects organizational performance significantly

\section{METHOD}

This research is to verify the causality theories from the previous. The type of analysis is quantitative. The population in the study is employees of PT. Bank Aceh Syariah as many as 1.899 people. The sample used is 137 employees as meeting the criteria of analysis tools that is Structural Equation (SEM) model, and is chosen with proportionate random sampling method.Data is collected using questionnaires. Likerd is used as a scale to measure the constructs. Data is analyzedusing Structural SEM with the help of the Amos program. The SEM equation model is a collection of statistical techniques that allow the simultaneous testing of a series of relatively complex relationships (Ferdinand, 2014). SEM is able to enter latent variables into the analysis. Latent variables are unobserved concepts that are approximated by observable or measured variables obtained by respondents through data collection methods (surveys, tests, observations) and are often called manifest variables (Ghozali, 2017).

\section{RESULT}




\section{International Journal of Business Management and Economic Review}

Vol. 2, No. 06; 2019

ISSN: 2581-4664

The analysis is a full model Structural Equation Model (SEM) analysis, after the analysis of the dimensionality level of the indicators forming latent variables tested with confirmatory factor analysis. Analysis of data processing results in the full SEM model stage is carried out by conducting a suitability test and a statistical test. The result of data processing for the full SEM model analysis is shown in figure below.

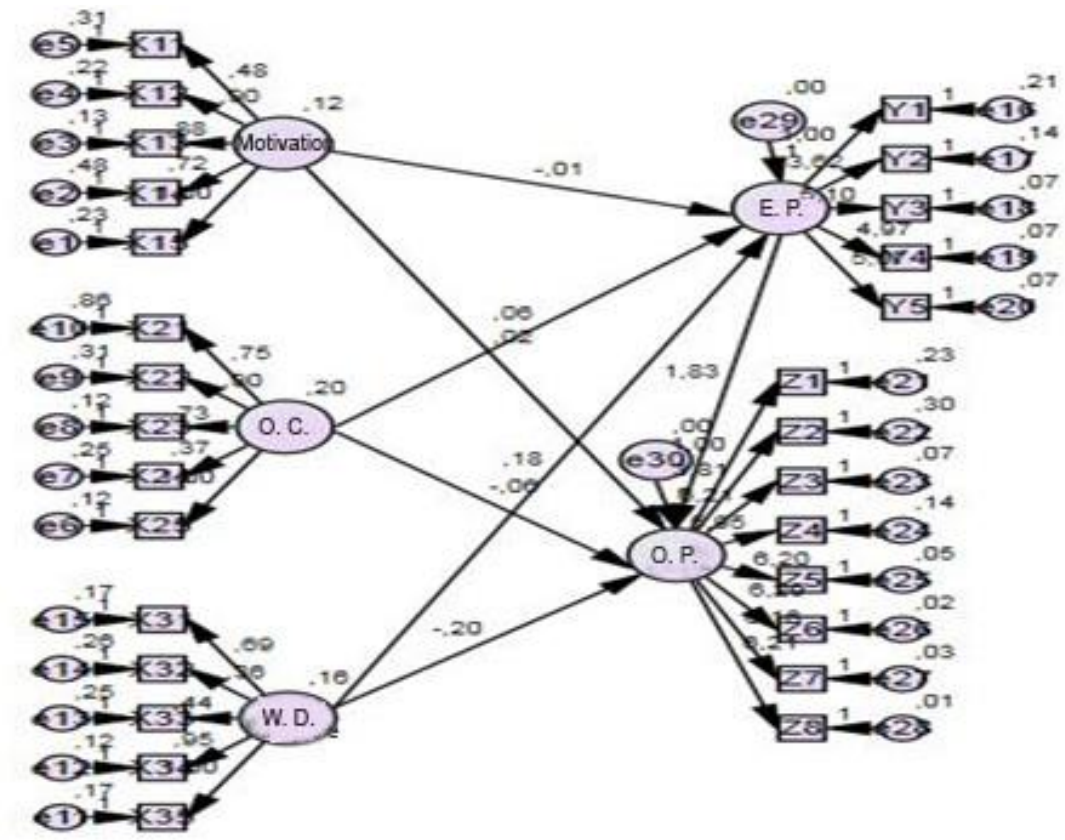

Figure 2. Structural Equation Model

Based on Figure 2, the 7 hypotheses of this research is carried out based on the Critical Ratio (CR) value of a causal relationship from the results of SEM processing as in the following interpretation.

\section{H1 is accepted : The effect of motivation on employee performance}

The influence of motivation on employee performance is significant with an estimate coefficient of $0.241(24.1 \%)$, the standardized estimate value of 0.089, the value of CR (Critical Ratio) is 2.313 and the probability value is 0.021 . Based on the test of goodness-of-fit test and regression weight standard test, the indicator has strong form latent construct, both exogenous and endogenous constructs. In other words, the motivation variable has a significant effect on the performance of employees of PT. Bank Aceh Syariah

\section{$\mathrm{H} 2$ is accepted : The effect of organizational climate on employee performance}

The influence of organizational climate on employee performance is significant with an estimate coefficient of $0.242(24.2 \%)$, the standardized estimate value of 0.103 , the value of CR (Critical 


\section{International Journal of Business Management and Economic Review}

Vol. 2, No. 06; 2019

ISSN: 2581-4664

Ratio) is 2.252 and the probability value is 0.024 . This situation shows that indicators forming latent constructs are strong indicators of construct measurements in this research model. Based on the goodness-of-fit test and regression weight standard test, the indicators have been strong in forming latent constructs, both exogenous and endogenous constructs. In other words, organizational climate variable has a significant effect on the performance of employees of PT. Bank Aceh Syariah.

\section{H3 is accepted : The effect of work discipline on employee performance}

The effect of work discipline variables on employee performance is significant with an estimate coefficient of $0.271(27.1 \%)$, the standardized estimate value is 0.063 , the CR (Critical Ratio) value is 3.193 and the probability value or significant is 0.001 . This situation shows that indicators forming latent constructs are strong indicators of construct measurements in this research model. Based on the goodness-of-fit test and regression weight standard test, the indicators have been strong in forming latent constructs, both exogenous and endogenous constructs. In other words, work discipline variable has a significant effect on the performance of employees of PT. Bank Aceh Syariah.

\section{H4 is accepted :The effect of motivation on organizational performance}

The influence of the variable motivation on organizational performance is significant with an estimate coefficient of $0.252(25.2 \%)$, the standardized estimate value is 0.074 , the value of CR (Critical Ratio) is 3.020 and the probability value or significant is 0.003 . This situation shows that indicators forming latent constructs are strong indicators of construct measurements in this research model. Based on the goodness-of-fit test and regression weight standard test, the indicators have been strong in forming latent constructs, both exogenous and endogenous constructs. In other words, the motivation variable has a significant effect onorganizational performance. Bank Aceh Syariah.

\section{H5 is accepted : The effect of organizational climate on organizational performance}

The influence of organizational climate variables on organizational performance is significant with an estimate coefficient of $0.475(47.5 \%)$, the standardized estimate value of 0.096 , the value of CR (Critical Ratio) is 4.896 and the probability value is significant at 0.000 . This situation shows that indicators forming latent constructs are strong indicators of construct measurements in this research model. Based on the goodness-of-fit test and regression weight standard test, the indicators have been strong in forming latent constructs, both exogenous and endogenous constructs. In other words, organizational climate variable has a significant effect on organizational performance of Bank Aceh Syariah.

\section{H6 is accepted : The effect of work discipline on organizational performance}

The influence of work discipline variables on organizational performance is significant with an estimate coefficient of $0.270(27 \%)$, the standardized estimate value is 0.054 , the CR (Critical 


\section{International Journal of Business Management and Economic Review}

Vol. 2, No. 06; 2019

ISSN: 2581-4664

Ratio) is 3.830 and the probability value is significant at 0.000 . This situation shows the indicators forming latent constructs are indicators that are strong enough in construct measurements in this research model. Based on the test of goodness-of-fit test and regression weight standard test, the indicator is strong enough to form a latent construct both exogenous and endogenous constructs. In other words, work discipline variable has a significant effect on the organizational performance of PT. Bank Aceh Syariah.

\section{H7 is accepted : The effect of employee performance on organizational performance}

The influence of employee performance variables on organizational performance is significant with an estimate coefficient of 0.193 (19.3\%), the standardized estimate value of 0.081 , the value of CR (Critical Ratio) is 2.495 and the probability value is 0.013 . This situation shows that indicators forming latent constructs are strong indicators of construct measurements in this research model. Based on the goodness-of-fit test and regression weight standard test, the indicators have been strong in forming latent constructs, both exogenous and endogenous constructs. In other words, the variable employee performance has a significant effect on the organizational performance of PT. Bank Aceh Syariah.

\section{CONCLUSION}

The result describes that motivation effects employee performance significantly, organizational climate effects employee performance significantly, work discipline effects employee performance significantly, motivation effects organizational performance significantly, organizational climate effects organizational performance significantly, work discipline effects $n$ organizational performance significantly, and employee performance effects organizational performance significantly. These all findings strengthen the previous theories and being the new premises. Work discipline is the biggest factor affecting the performance of employees of PT. Bank Aceh Syariah. Motivation is also the most dominant factor affecting the organizational performance of PT. Bank Aceh Syariah. This model can be a basic for another research in further and this also can enrich the realm of knowledge especially in management. For practical managers, this is also as a reference for leaders to consider and pay more attention to the variables related. The limitation lies in the number of variables and object.

\section{REFERENCES}

Armstrong, M. (2006) Strategic Human Resource Management-A Guide to Action 3rd Ed. 3rd Editio. London and Philadelphia. Available at: http://repository.umpwr.ac.id:8080/bitstream/handle/123456789/521/Strategic Human Resource Management -A Guide to Action 3rd Ed.pdf?sequence=1.

Dodi, R., Mukhlis and Amri (2013) 'Effect of Organizational Climate, Work Ethics and Discipline on Employee Performance and Its Impact on the Performance of PT. Arun NGL. Lhokseumawe Aceh'. Banda Aceh: Universitas Syiah Kuala.

Fahmi, I. (2011) Analisa Laporan Keuangan. Bandung: Alfabeta.

Ferdinand, A. (2014) Metode Penelitian Manajemen. Edisi 5. Semarang: Universitas Diponegoro. 


\section{International Journal of Business Management and Economic Review}

Vol. 2, No. 06; 2019

ISSN: 2581-4664

Ghozali, I. (2017) Model Persamaan Struktural, Konsep dan Aplikasi dengan Program AMOS 24 Update Bayesian SEM. Edisi 7. Semarang: Badan Penerbit Universitas Diponegoro.

Gibson, D. E. and Callister, R. R. (2010) 'Anger in organizations: Review and integration', Journal of Management, 36(1), pp. 66-93. doi: 10.1177/0149206309348060.

Halimah, Mukhlis and Amri (2016) 'The Effect of Work Motivation, Leadership, Discipline and Job Stress on Employee Performance and Its Implications on the Performance of the Aceh Social Service'. Banda Aceh: Universitas Syiah Kuala. Available at: etd.unsyiah.ac.id.

Mangkunegara, A. P. (2013) Manajemen Sumber Daya Manusia Perusahaan. Bandung: Remaja Rosdakarya.

Sinungan, M. (2011) Produktivitas : Apa dan Bagaimana. Edisi 2. Jakarta: Bumi Aksara.

Sulityani, A. T. (2009) Manajemen Sum-ber Daya Manusia Konsep Teori Dan Pengembangan Dalam Konteks organisasi Public. Ed. 2 Cet. Yogyakarta: Graha Ilmu. 